7. Reprod. Fertil. (1964) 8, 325-330

\title{
HISTO-IMMUNOLOGICAL LOCALIZATION OF HYALURONIDASE IN THE BULL TESTIS
}

\author{
R. E. MANGINI, A. ALONSO, J. BARQUET, B. ALVAREZ AND \\ M. NEMIROVSKY \\ Departamento de Histologia, Facultad de Medicina, \\ Universidad de Buenos Aires, Argentina
}

(Received 6th April 1964)

\begin{abstract}
Summary. A highly purified and potent hyaluronidase preparation extracted from bull testis was employed to induce heterologous antibody by sensitizing adult rabbits. Specific anti-enzyme antibodies were demonstrated by Ouchterlony's method, and by passive cutaneous anaphylaxis (PCA), and haemagglutination and complement fixation tests. In order to localize the cellular site of the accumulation of the enzyme, direct and indirect immunofluorescent techniques were applied to tissue sections and to isolated germ cells of adult bull testis. Specific fluorescence adequately checked by control reactions appeared in the perinuclear area of spermatids, in the acrosomes of spermatozoa and with less certainty in the cytoplasm of other cells tentatively identified as spermatocytes. Non-specific fluorescence could be seen in the basal cell line of the seminiferous tubules.
\end{abstract}

\section{INTRODUCTION}

The concentration of hyaluronidase in the testis and its relation to the presence of mature germ cells has been extensively studied. It increases with the maturation of the testis (Sprunt, Hooker \& Raper, 1939) and decreases with experimental atrophy of germinal epithelium (Sprunt et al., 1939; Leonard, Perlman \& Kurzrok, 1948; Steinberger \& Nelson, 1955, 1957; Grief, 1954). Furthermore, it was shown that the enzyme activity of the testis is detectable when the primary (Riisfeldt, 1949-50) or the secondary spermatocytes first appear (Tsiper, 1953) and that of the semen is proportional to its sperm density (Bergenstal \& Scott, 1948; Sherber, Birnberg \& Kurzrok, 1948; Swyer, 1947). Since the antigenic potency of crude preparations of hyaluronidase was demonstrated (Tyler, 1948; Katsh, 1960), Yaeger \& Anderson (1959) used the fluorescent antibody technique to localize the site of the cellular accumulation of the enzyme in the bull testis. The results suggested that the spermatogonia and spermatocytes produce the enzyme, and so prompted us to reinvestigate the problem using a more highly purified enzyme preparation, specific immunoserological tests and a histo-immunological technique of higher resolution, in order to demonstrate the cellular localization of the antigen. 


\section{MATERIAL AND METHODS}

The hyaluronidase preparation used was obtained from testis of adult and healthy bulls. Chemical technique applied involved the use of cold ethanolic fractionation procedure (Freeman, Anderson, Nebster \& Dorfman, 1950) and the chromatography on IRC-50 resin (Brunish \& Högberg, 1960). The last one provides an enzyme preparation of extreme purity and higher potency. The homogeneity, aminoacid and sugar composition of the enzyme thus obtained was already reported (Brunish \& Högberg, 1960). Enzyme samples of 160,000 i.u./mg $\mathrm{N}$ activity were obtained as measured by turbidimetric procedure (Tolksdorf, 1954).

Injections of $6 \mathrm{mg}$ of the enzyme dissolved in $1 \mathrm{ml}$ of phosphate buffer, $\mathrm{pH}$ $7 \cdot 2$, were made into the ear veins of four healthy adult rabbits for 4 successive days and interrupted for 3 days, making a total of 4 weeks of sensitization. The animals were then bled from the heart and the serum was heated at $56^{\circ} \mathrm{C}$ for $20 \mathrm{~min}$ to inactivate the non-specific hyaluronidase inhibitor. The antibody level was detected by complement fixation (Casals \& Palacios, 1941), haemagglutination (Boyden, 1951), double gel diffusion (Ouchterlony, 1958) and the PCA technique (Ovary, 1958). Positive results were obtained when the enzyme was used in doses of $8 \mathrm{mg} / \mathrm{ml}$ of saline solution or, in the Ouchterlony technique, $30 \mathrm{mg} / \mathrm{ml}$. Specificity was checked by performing similar tests with normal rabbit serum and by the immune absorption procedure $(1 \mathrm{ml}$ of the antisera incubated in vitro at $37^{\circ} \mathrm{C}$ for $3 \mathrm{hr}$ in the presence of $60 \mathrm{mg}$ of the antigen and then centrifuged). The possibility of serum protein contaminants of the enzyme preparation was investigated by complement fixation and by the Ouchterlony technique using bull albumin and globulin fractions in doses of $10 \mathrm{mg} / \mathrm{ml}$ of saline solution. For the histo-immunological studies fragments of testis of fertile bulls were immediately frozen and sections 4 to $6 \mu$ in thickness were used, unfixed or treated with formaldehyde vapours, for $15 \mathrm{~min}$. Both the direct and the indirect techniques were applied (Coons, 1958).

In the first case, the unlabelled immune serum was followed by the labelled goat globulin anti-rabbit globulin fraction (Microbiol. Assoc. U.S.A.). In the second case, only the labelled globulin fraction of the immune serum was used. This was separated by a saline fractionation procedure and adjusted to a concentration of $20 \mathrm{mg}$ of protein per $\mathrm{ml}$ for conjugation with fluorescein isothiocyanate (Riggs, Seiwald, Burkhalter, Downs \& Metcalf, 1958). Unconjugated fluorescein and non-specific fluorescence were removed by dialysis against phosphate buffer saline $\mathrm{pH} 7 \cdot 1$ at $4^{\circ} \mathrm{C}$ followed by absorption with guinea-pig liver powder or passage through a column of Sephadex G25 (Fotherhill \& Nairn, 1961). Samples of unconjugated globulin were kept at $-25^{\circ} \mathrm{C}$ for control blocking reactions. Specificity for both immunofluorescent techniques were controlled with the following incubations: (1) normal rabbit serum or its globulin fraction; (2) other immune sera like rabbit serum (or its globulin fraction) anti-bull collagen or kidney; (3) blocking tests with unconjugated antihyaluronidase serum or its globulin fraction; (4) immune serum subjected to previous in-vitro absorption of the antigen.

Since the cellular localization of the antigen was difficult to assess in the tissue preparations, a monolayer of testicular cells was prepared. Several blocks 
of tissue were immersed in a test tube containing $10 \mathrm{ml}$ of a cold Melnick Hank's solution $\mathrm{pH} \mathrm{7.2}$ and repeatedly cut into smaller pieces. Then a volume of $20 \mathrm{ml}$ of $0.25 \%$ trypsin dissolved in Hank's solution was added and incubated at $37^{\circ} \mathrm{C}$ for $20 \mathrm{~min}$. Dissociation of the cells was accelerated when the medium was aspirated and ejected with the aid of a pipette. The dissociated tissue was filtered by double gauze and centrifuged for $10 \mathrm{~min}$ at $600 \mathrm{rev} / \mathrm{min}$. The cells were re-suspended in Melnick Hank's solution and a volume of $2 \mathrm{ml}$ containing 80 million cells was transferred to Layton tubes and incubated for $90 \mathrm{~min}$ at $37^{\circ} \mathrm{C}$. After this time morphologically well-preserved cells were sedimented on the slides. This material was then fixed with formaldehyde vapour or simply kept unfixed in the icebox at $4^{\circ} \mathrm{C}$ over night until use. The immunofluorescent techniques and the corresponding control reactions were applied as in tissue sections. The preparations were studied with a Leitz Ortho Lux fluorescent microscope, and by phase contrast; analogous specimens were stained with haematein eosin and periodic acid Schiff reagent, in order to identify the germinal cell types by their size and structure, and the presence of the acrosome.

\section{RESULTS}

Immunoserological tests revealed in the blood of sensitized rabbits the presence of circulating antihyaluronidase antibodies. Results obtained were: (a) 1/256 for the complement fixation test; (b) complete haemagglutination at 1/6240 in the Boyden technique; (c) a blue dermal spot of $2 \mathrm{~cm}$ diameter, with $1 / 8$ diluted antisera and an optimal time response around $24 \mathrm{hr}$ in the PCA test; (d) a compact and homogenous band appears at 4 days with pure and half-diluted antisera in the Ouchterlony technique. When parallel tests were performed with normal rabbit serum the results were constantly negative. Negative or very low titres were also obtained when the previously absorbed immune sera was used; it was negative for PCA and Ouchterlony techniques, $1 / 16$ for complement fixation test and 1/256 for haemagglutination. Bull albumin and globulin fractions were not present in the hyaluronidase preparation as the induced antibody showed negative results when these proteins were tried in the serological tests. Localization of fluorescence was very similar in the tissue sections or in the isolated cells when the histo-immunological procedure was applied by the direct or indirect method. Positive reactions appeared in the unfixed specimens as well as in the formalin fixed material, but morphological preservation was better in the latter. Brighter specific fluorescence as well as diminished non-specific fluorescence were obtained in this system with labelled immune globulins treated with Sephadex, as compared with the same one purified with liver powder.

In tissue sections specific yellowish-green fluorescence appeared in the major part of seminiferous tubules localized in the cells of the germinal epithelium; the reaction was slight or negative in other parts of the testis (Pl. 1, Figs. 1 to 4). Due to the thickness of the sections and to indifferent preservation it was difficult to identify the individual types of germinal cells. Nevertheless, comparison with alternate sections stained with haematein eosin and by PAs techniques showed that the antibody had united with the antigen in the middle and late cellular stages of spermatogenesis. 
Examination of isolated testicular cells revealed specific fluorescence in some of them whereas others did not react at all (Pl. 1, Fig. 5). Examination by phase contrast, and preparations stained with haematein eosin and PAS techniques, suggested that the fluorescent cells were spermatids and spermatozoa, and perhaps some were spermatocytes (Pl. 1, Figs. 6 and 7). The reaction appeared to be confined to the perinuclear zone, or to the cytoplasm in the presumed spermatocytes; it covered part of the nuclei of the spermatids and was clearly seen in the acrosomic area of the spermatozoa. No evidence of specific fluorescence could be detected in the nuclei, midpiece and tail of the spermatozoon ( $\mathrm{Pl} .1$, Figs. 8 to 11). The induced fluorescence thus obtained appeared to be highly specific, since in the control reactions it was slight or absent. This was especially true of the normal rabbit serum or its globulin fraction, in blocking reactions and immune absorbed sera. In some of these control preparations, as when unstained preparations were examined, granules of arange-yellow autofluorescence were seen in the Leydig cells and in other cells which were presumed to be spermatogonial and Sertoli cells.

\section{DISCUSSION}

These studies contribute direct histo-immunological evidence to support the contention that hyaluronidase is present not only in spermatozoa but also in spermatids and probably in spermatocytes. The specificity of these findings is backed by the highly purified state and known chemical composition of the antigen used, and the satisfactory results of control reactions in the serological and immunofluorescent tests. Since no other protein groups appear to be present in the preparation used (Brunish \& Högberg, 1960) it is presumed that the enzyme mucoprotein is responsible for the antigenic property. The higher resolution provided by the monolayer of testicular cells, and comparison with similarly stained material, show that the antigen resides predominantly in the perinuclear region in the spermatids, in the acrosomic system of the spermatozoa and in some area of the cytoplasm in the (presumed) spermatocytes. These results are consistent with the observations of other authors, referred to earlier, as regards the correlation between the enzyme content of the testis and the presence

\section{EXPLANATION OF PLATE 1}

FIG. 1. Section of bull testis incubated with labelled normal rabbit globulins. Pale spontaneous fluorescence is seen in the seminiferous tubules and intertubular structures. $\times 450$. FIG. 2. Section of bull testis incubated with labelled normal rabbit globulins. Bright spontaneous fluorescence appears in the basal cell line in some tubules (e.g. Fig. 1) $\times 450$. FIg. 3. Section of bull testis with labelled rabbit globulin anti-bull testis hyaluronidase. Bright specific fluorescence is shown inside the tubules and in most of the cells of the germinative epithelium. $\times 450$.

FIg. 4. Section of bull testis incubated with labelled rabbit globulin anti-bull testis hyaluronidase. Specific fluorescence in a dense clump of germinal cells. $\times 450$.

Fig. 5. Isolated testicular cells incubated with labelled antihyaluronidase antibody. Specific fluorescence is present in some cells while a spontaneous fluorescence appears in others. $\times 450$.

FIGS. 6 and 7. Two cells, presumably spermatocytes, showing specific fluorescence throughout the cytoplasm (Fig. 6) or concentrated in the perinuclear zone (Fig. 7) $\times 950$. Figs. 8 and 9 . Two spermatids with specific bright fluorescence surrounding the nucleus (Fig. 8) or at one pole (Fig. 9). $\times 1150$.

FIgs. 10 and 11 . Two spermatozoa showing specific fluorescence located in the intact acrosome (Fig. 10) or in distorted masses of the same structures (Fig. 11). $\times 1150$. 

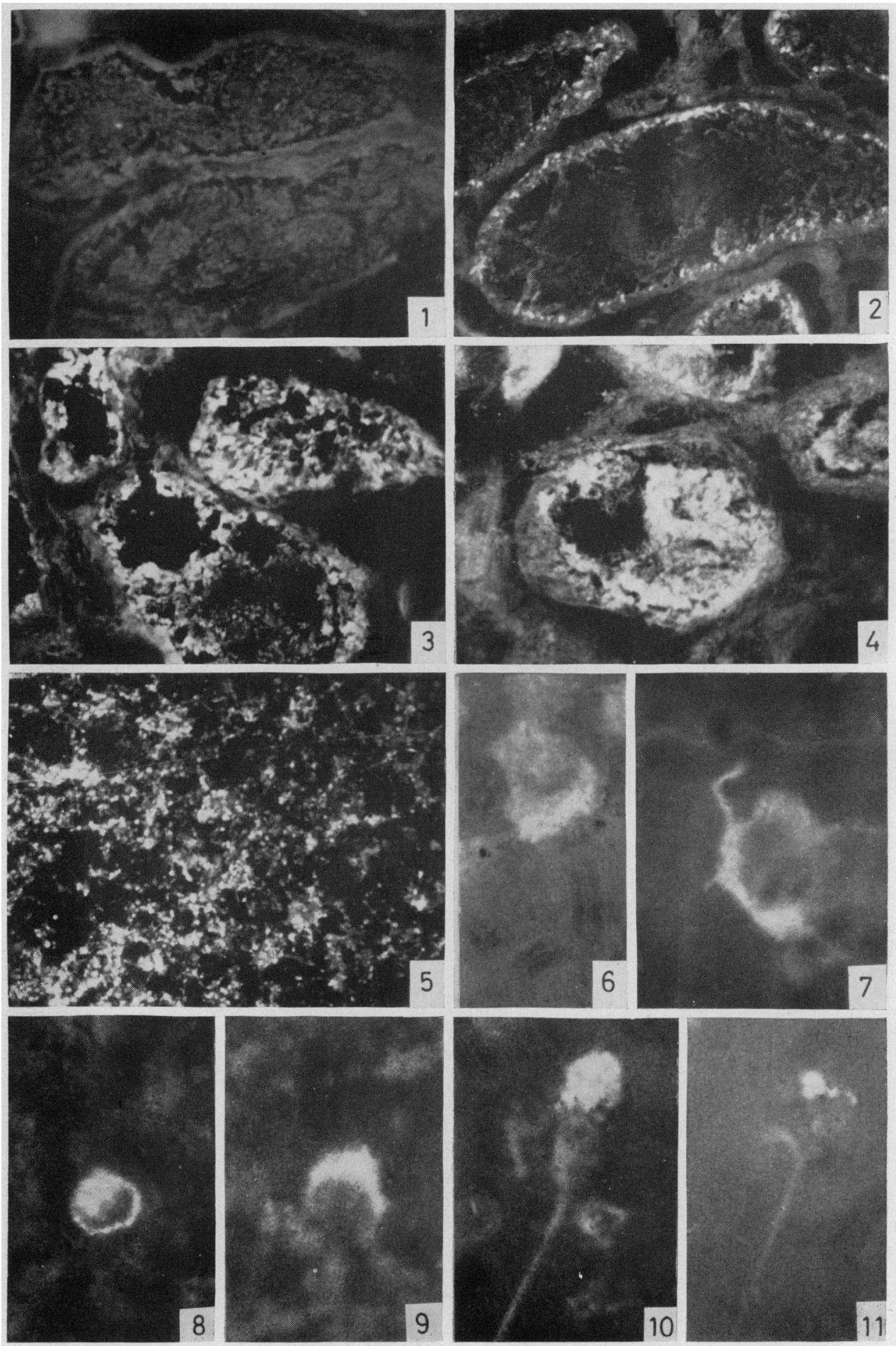

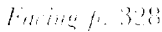


of spermatocytes and of cells in later stages of spermatogenesis. More specifically it was shown that the decapitated heads of spermatozoa of the Guernsey bull contain far more hyaluronidase than the sperm tails (Masaki \& Hartree, 1962) and that the enzyme is released from spermatozoa treated with digitonin (Austin, 1960) or weak alkaline solutions, which also removed the PAs-staining material and carbohydrates from the acrosome (Clermont, Glegg \& Leblond, 1955; Hathaway \& Hartree, 1963). Consequently, the histo-immunological detection of the enzyme in the earlier stages of spermatids and in the spermatozoa, together with the presence of a PAS substance in similar cytoplasmic areas of these cells, suggests a correlation of both reactions; this is supported by the fact that the antigen is chemically a mucoprotein. Similar histo-immunological results were obtained in our laboratory by incubating guinea-pig germinal cells and labelled homologous antitesticular hyaluronidase globulins. Furthermore, the acrosomes of guinea-pig and human germ cells react with homologous antitestis serum using the indirect Coons's technique; this suggests that the enzyme might be one of the antigenic determinants contained in the testicular extract used for sensitization (Mancini, Davidson, Vilar, Nemirovsky \& Bueno, 1962; Mancini, 1964).

The different results obtained by athers (Yaeger \& Anderson, 1959) who have used fluorescent antihyaluronidase bull antibody, might be attributable to the less purified antigen used, lower sensitivity of the techniques applied, and possibly to a misinterpretation of the fluorescent images observed, especially when granules of orange-yellow autofluorescence were encountered in control preparations, as described above.

\section{ACKNOWLEDGMENTS}

This work was supported by a grant from The Population Council Inc., New York.

The authors are indebted to Ocefa Medical Products, Buenos Aires, for their help in the preparation of the enzyme.

\section{REFERENGES}

Ausris, C. R. (1960) Capacitation and the release of hyaluronidase from spermatozoa. F. Reprod. Fertil. 1,310 .

Bergenstal, D. M. \& Scotr, W. W. (1948) Studies on hyaluronidase. F. Amer. med. Ass. 137, 1507.

BOYDEN, S. V. (1951) The absorption of proteins on erythrocytes treated with tannic acid and subsequent hemagglutination by antiprotein sera. 7. exp. Med. 93, 107.

BRUNish, R. \& HöGBERG, B. (1960) Some of the properties of purified testicular hyaluronidase. $C . R$. Lab. Carslberg, 47, 32.

Casals, J. \& Palacios, R. (1941) The complement fixation test in the diagnosis of virus infection of the central nervous system. F. exp. Med. 74, 409.

Clermont, J., GlegG, R. E. \& Leblond, G. P. (1955) Presence of carbohydrates in the acrosome of guinea pig spermatozoa. Exp. Cell Res. 8, 453.

Coons, A. H. (1958) Fluorescent antibody method in general cytochemical methods, p. 399. Ed. J. F. Danielli. Academic Press, New York.

Fotherhill, J. E. \& NAIRN, R. G. (1961) Purification of fluorescent protein conjugates: comparison of charcoal and Sephadex. Nature, Lond. 192, 1073.

Freeman, M. E., Anderson, P., Nebster, M. E. \& Dorfman, A. (1950) Ethanolic fractionation of bovine testicular hyaluronidase. 7. biol. Chem. 186, 201.

GRIEF, R. L. (1954) Extraction and colorimetric measurement of rat testicular hyaluronidase. F. biol. Chem. 206, 381.

HATHAWAY, R. R. \& HARTREe, E. F. (1963) Observations on the mammalian acrosome; experimental removal of acrosome from ram and bull spermatozoa. F. Reprod. Fertil. 5, 225. 
KATSH, S. (1960) The anaphylactogenicity of testicular hyaluronidase and a species difference in testicular hyaluronidase demonstrated by isolated organ anaphylaxis. Int. Arch. Allergy, 17, 70.

Leonard, S. L., Perlman, P. L. \& Kurzrok, R. (1948) Hyaluronidase levels of rat testes as related to age, hypophysectomy and cryptorchidism. Endocrinology, 42, 176.

Mancini, R. E., Davidson, O. W., Vilar, O., Nemirovsky, M. \& Bueno, M. P. (1962) Localization of acrosomal antigenicity in guinea pigs. Proc. Soc. exp. Biol., N.Y. 3, 435.

Mancini, R. E. (1964) Allergic aspermatogenesis experimentally induced in man and animals. Injury, allergy and inflammation, p. 365. Ed. E. D. Thomas. Waverly Press, Baltimore.

Masaki, J. \& Hartree, E. F. (1962) Distribution of metabolic activities, phospholipid and hyaluronidase between the heads and tails of bull spermatozoa. Biochem. 7. 84, 347.

Ouchterlony, O. (1958) Diffusion in gel methods for immunological analysis. Progr. Allergy, 5, 1.

OVARY, Z. (1958) Immediate reactions of the skin of experimental animals provoked by antigen-antibody interaction. Progr. Allergy, 5, 459.

Riggs, J. L., Seiwald, R. J., Burkhalter, J. H., Downs, C. M. \& Metcalf, T. G. (1958) Isothiocyanate compounds as fluorescent labeling agents for immune serum. Amer. 7. Path. 34, 1081.

RIISFELDT, O. (1949-50) Der ursprung von hyaluronidase in der rattenhoden. Z. Vitamin-Hormon-u. Fermentforsch, 3, 66 .

Sherber, D. A., Birnberg, C. H. \& Kurzrok, R. (1948) Viscosimetric determination of the hyaluronidase content of spermatozoa. Endocrinology, 42, 20.

Sprunt, D. H., Hooker, C. W. \& Raper, J. S. (1939) Relation of spermatogenesis to the factor in the testis which increases tissue permeability. Proc. Soc. exp. Biol., N.Y. 41, 398.

Steinberger, E. \& Nelson, W. (1955) The effect of hypophysectomy, cryptorchidism, estrogen and androgen upon the level of hyaluronidase in the rat testis. Endocrinology, 56, 429.

Steinberger, E. \& Nelson, W. (1957) The effect of Furadroxyl treatment and X-irradiation on the hyaluronidase concentration of the rat testis. Endocrinology, 60, 105.

Swyer, G. I. M. (1947) The release of hyaluronidase from spermatozoa. Biochem. 7. 41, 413.

Tolksdorf, S. (1954) The in vitro determination of hyaluronidase. Meth. biochem. Anal. 1, 425.

TsIPER, S. M. (1953) Dependence between the seminal development and hyaluronidase activity. C.R. Acad. Sci. U.R.S.S. 91, 351. Abstract in Chem. Absts. 47, 11419c.

Tyler, A. (1948) Fertilization and immunity. Physiol. Rev. 28, 180.

YAEger, J. A. \& ANDERson, T. O. (1959) Localization of testicular hyaluronidase using fluorescent antibody. Acta Anat. 39, 189. 